\title{
Estimation of Aerial Biomass of Lychnophora ericoides (Mart.)
}

\author{
Brunno Santana de Andrade ${ }^{1}$ and John Du Vall Hay ${ }^{2 *}$ \\ ${ }^{1}$ Departamento de Engenharia Florestal; ${ }^{2}$ Departamento de Ecologia; Universidade de Brasilia; C.P. 04457; \\ jhay@unb.br; 70.904-901; Brasília - DF - Brasil
}

\begin{abstract}
For sustainable use of native plant species, knowledge of the amount of harvestable biomass is necessary. This study presents data on allometric relationships of Lychnophora ericoides Mart. (Asteraceae), an extractive resource in the Cerrado region of Brazil. On the Fazenda Água Limpa (15 $\left.45^{\prime} \mathrm{S}, 47^{\circ} 57^{\prime} \mathrm{W}\right)$ of the Universidade de Brasilia, 38 individuals of this species were measured in the field, the parts above ground were harvested, separated into components and oven dried. The best regression equations to estimate biomass were geometric and the best fit was between total height and total biomass $\left(r^{2}=0.923\right)$. The economically useful portions, the leaves and branches accounted for approximately $20 \%$ of total above ground dry weight, but when used as the dependent variable, the strength of the relationship decreased $\left(r^{2}=0.694\right)$. The relationship between branch diameter and leaf biomass was similar to that between height and leaf dry weight $\left(r^{2}=0.600\right)$. The relation between the number of leaves and their biomass was linear but weak. The development of these equations is the first step towards the implementation of plans for sustainable use of this species.
\end{abstract}

Key words: Allometric relationships, sustainable development, Cerrado

\section{INTRODUCTION}

The Cerrado occupies approximately $20 \%$ of Brazil and is considered to be a region with an enormous potential for agriculture (Goedert et al., 1980). Due to these pressures, the Cerrado is undergoing rapid alterations on a large scale (Alho and Martins, 1995), provoking radical changes in plant community composition. However, within the native vegetation of the Cerrado, there are still many species with a large potential for economic use and it may be possible that on a longer time scale the overall value of the region is greater if rational and sustainable use of native plant resources is implemented (Pires and Scardua, 1998; Sawyer et al., 1997). One of the rational uses of native plant species is in the production of medicine by local communities (Carvalho, 2004; Ferreira et al., 1998; Vieira and Silva, 2002). In spite of the great floristic richness in tropical regions, probably less than $1 \%$ of this potential has been studied although in the Cerrado region the situation is slightly better, with around $3 \%$ of the flora being used (Vieira and Martins, 2000).

Previous studies on biomass of native plant species in the Cerrado have concentrated on aspects of initial growth (Hoffmann and Franco, 2003; Ruggiero and Zaiden, 1997), aspects related to ecophysiology (Franco, 1998) or root-shoot ratios (Moreira and Klink 2000). Dimension analysis (Whittaker, 1968) is a technique that has been widely used in the estimation of primary

* Author for correspondence 
production (Clark et al., 2001) and above ground biomass (Cairns et al., 2003). Although this method has generally been used on species that are large in size, it may also be used for the estimation of biomass in smaller species (Ludwig et al., 1975). In Brazil, this method has mainly been used in the studies of economically important species for the estimation of wood production (Reis et al., 1985), or the aerial biomass of natural communities (Keller et al., 2001; Kuntschik and Bittencourt, 2003) however some studies on native and economically important species are available (Veja et al., 2004). There are few published studies in Brazil on how the extractive process affects plant population dynamics or how the removal of aboveground parts affects the survival or the capacity of local plant populations to furnish raw material (Borges Filho and Felfili, 2003; Silva and Hay, 2003).

The genus Lychnophora is found in the Cerrado region of Brazil where there are approximately 25 species. These are shrubs and usually are found in high altitude fields. Lychnophora ericoides, commonly known as "arnica" occurs in the Federal District and the states of Goiás and Minas Gerais at elevations between 950 and $1800 \mathrm{~m}$ above sea level, being found in sandy or quartz soils (Coile and Jones, 1981). In the Federal District of Brazil many species of plants are considered to be threatened due to the combination of low density of individuals, to intense extractive pressure or due to habitat destruction and Lychnophora ericoides can be included in this group of threatened species (Filgueiras and Pereira, 1994). The leaves and branches of this species are collected extractively and are used in the preparation of medicaments, both by local communities and commercially. These remedies, sold as either ointments or creams have excellent anti-inflammatory mechanisms (Borsato et al., 2000). To the present time, most studies on this species have focused on the biochemical characterization of compounds found in the leaves, branches and roots of this species (Sakamoto et al., 2003).

Considering the importance of the leaves and branches of Lychnophora ericoides as an extractive resource and the need to obtain data on the sustainability of this species the objectives of this study were to calculate allometric relationships to estimate the aerial biomass of Lychnophora ericoides and also to verify if the relationship between branch size and leaf biomass was constant. These equations may be useful in permitting a rapid estimation of available biomass and thus aid in planning for sustainable use of this species.

\section{MATERIAL AND METHODS}

\section{Field methods}

A total of 38 individuals of Lychnophora ericoides (Asteraceae) were collected between September 2003 and May 2004 from a natural population on the Fazenda Água Limpa of the Universidade de Brasília $\left(15^{\circ} 45^{\prime} \mathrm{S}, 47^{\circ} 57 \mathrm{~W}\right)$, located $25 \mathrm{~km} \mathrm{SW}$ of the center of Brasília in central Brazil. Based on previous studies of population structure of this species in the same area (Hay, unpublished), individuals were selected to assure a representative sample of the height variation of $L$. ericoides in this area. All the individuals had a typical growth form and deformed or dying individuals were not selected. To be consistent with previous studies (Hay, unpublished), the following measurements were made in the field: 1) Total height, from soil surface to top of crown $(\mathrm{m})$; 2) Distance from the soil surface to the base of the first live branch (m); 3) Stem circumference at $20 \mathrm{~cm}$ above the soil surface $(\mathrm{cm})$; 4) Dimensions of the canopy (long and small axis) (m); 5) Number of live and dead branch modules (at least $10 \mathrm{~cm}$ in length); 6) Branching order; and 7) Presence of reproductive structures (current or past). After these measurements, the individuals were cut at soil level and taken to the laboratory for processing.

Another data set consisting only of first order branches (branches without bifurcations) with leaves was collected to evaluate the relation between branch size and leaf biomass. This data set was composed of 34 branches collected from individuals that were not used in the whole individual evaluation. For these samples the following measurements were made: 1) Diameter of the branch at the point of insertion into the main stem, measured with a vernier calipers $(\mathrm{cm}) ; 2)$ The total length of the branch $(\mathrm{cm})$; and 3) The length of the branch covered with leaves $(\mathrm{cm})$. After these measurements the branch was cut at the point of insertion and taken to the laboratory for processing.

\section{Laboratory methods}

In the laboratory, each entire individual was separated into components of: 1) live branch 
modules, 2) leaves, 3) dead branch modules, 4) stem, and 5) reproductive structures. Each component was dried separately in a forced draft oven at $60^{\circ} \mathrm{C}$ until constant weight. The dry weight of each component was measured using an OHAUS balance (Precision Plus TP400D). During the processing of these individuals 30 branches with leaves were separated and the number of leaves present on these branches was counted and they were dried to provide data on the relationship between number of leaves and biomass.

For the analysis of the relation between branch size and leaf biomass, the leaves of each selected branch were removed, counted and each component was dried separately in a forced draft oven at $60^{\circ} \mathrm{C}$ until constant weight.

\section{Data analysis}

For the whole plants, all field measurements were considered to be independent variables. Crown area was also calculated based on the formula for an ellipse for those individuals with a branching order of 2 or higher. The dry weight of each component and their sum (total) were considered to be dependent variables in the calculation of the allometric relations. To estimate biomass of only the economically useful parts of $L$. ericoides the sum of the dry weight of leaves and branches was also used as a dependent variable. Spearman correlation coefficients $\left(\mathrm{r}_{\mathrm{s}}\right)$ were calculated for all combinations of variables. All data were plotted and simple regression equations (linear, exponential, logarithmic and geometric) were calculated for each combination of independent and dependent variables, along with the calculation of the respective coefficient of determination $\left(\mathrm{r}^{2}\right)$. A multiple linear regression analysis was also calculated with biomass as the dependent variable. For the relationship between branch size and leaf biomass, the diameter, the number of leaves and length of the branch were considered to be the independent variables and dry weight was the dependent variable. In another analysis the number of leaves was used as the dependent variable instead of leaf biomass. All data were analyzed using BioEstat 3.0 (Ayres et al. 2003) and Statistix 8.0 (Analytical Software 2003).

\section{RESULTS}

The individuals collected for dimension analysis ranged in total height from 0.05 to $1.68 \mathrm{~m}$ (Tab. 1). At least four individuals were collected in each height class, except for the class $>1.5 \mathrm{~m}$ where only two individuals were collected. Fifteen (40\%) of the individuals collected had dead modules and reproductive structures were only observed in individuals above $0.27 \mathrm{~m}$ in height with a branching order of 2 or higher $(\mathrm{N}=25)$. However, only $12(48 \%)$ of the individuals over these minimum values had reproductive structures. Overall, the distribution of dry weight among components for all individuals collected was: $13.1 \%$ in the leaves; $9.8 \%$ in live modules, $71.3 \%$ in the stem, $1.5 \%$ in reproductive structures, and $4.3 \%$ in dead modules (Tab. 2). However, for individual components the ratios differed with size, for instance the proportion of dry biomass in the stem increased with individual size, ranging from less than $50 \%$ in individuals $<0.15 \mathrm{~m}$ tall to over $75 \%$ in the taller individuals. This variability is evident when the value of the standard deviation of each variable is compared with the mean for the same variable. For leaves and branches, in five (13\%) of the individuals branch dry weight was greater than leaf dry weight. The correlation between the number of leaves and their dry weight was significant $\left(r_{\mathrm{s}}=0.630, \mathrm{p}<0.001\right)$. In general, the correlation among the independent variables was statistically significant, with $r_{s}$ values greater than 0.570 ( $p<0.001)$. The combinations with non significant correlations were between live and dead modules $\left(\mathrm{r}_{\mathrm{s}}=0.247, \mathrm{p}=0.368\right)$ and stem circumference at $20 \mathrm{~cm}$ and height of first branch $\left(r_{s}=0.324, p=0.106\right)$. Between the dependent variables, all combinations had high correlation coefficients $\left(r_{s}>0.830, p<0.001\right)$.

As individuals increased in size, the scatter of the data points increased and the $r^{2}$ value tended to decrease. In general the best fit for these relationships were geometric regressions. The dry biomass of reproductive structures and dead modules were not included in the calculation of the regression equations since these components were not always present. For several data sets the predictive value of the equations was above $80 \%$. For example between total height $\mathrm{x}$ stem weight $\left(\mathrm{Y}=156.34 \mathrm{X}^{1.530} ; \mathrm{r}^{2}=0.923 ; \mathrm{p}<0.001\right)$, total height $x$ total weight $(\mathrm{p}<0.001$; Fig. 1A) and live modules $x$ leaf weight $\left(Y=4.074 \mathrm{X}^{0.997} ; \mathrm{r}^{2}=0.812\right.$; $\mathrm{p}<0.001)$. When stem diameter at $20 \mathrm{~cm}$ above 
the soil surface was used as the independent variable the $r^{2}$ values were lower than when total height was used. For example the relationship between stem diameter and total dry weight $(\mathrm{p}<$ 0.001 ; Fig. 1B). The relation between height and the sum of leaf and branch weight was lower than that for total dry weight but was also significant ( $\mathrm{p}$ $<0.001$; Fig. 1C) but greater than that for only leaf biomass $\left(Y=26.203 X^{1.009}, r^{2}=0.665, p<0.001\right)$. A multiple regression analysis using total height, stem circumference and crown area as the independent variables produced similar results to the previous regressions, for total weight $\left(r^{2}=\right.$ $0.879, \mathrm{p}<0.001)$ and for combined leaf and branch weight $\left(r^{2}=0.757, p<0.001\right)$.

Table 1 - Minimum and maximum values of the independent variables measured of Lychnophora ericoides in a Cerrado on the Fazenda Água Limpa, Brasília, central Brazil. $\mathrm{N}$ is the sample size for each variable.

\begin{tabular}{lcccccccccc}
\hline & $\begin{array}{c}\text { Total } \\
\text { Height } \\
(\mathbf{m})\end{array}$ & $\begin{array}{c}\text { Height of } \\
\mathbf{1}^{\text {st }} \\
\text { branch } \\
(\mathbf{m})\end{array}$ & $\begin{array}{c}\text { Stem. } \\
\text { diam. at } \\
\mathbf{2 0} \mathbf{~ c m} \\
\mathbf{( c m )}\end{array}$ & $\begin{array}{c}\text { Max. } \\
\text { canopy } \\
\text { width (m) }\end{array}$ & $\begin{array}{c}\text { Min. } \\
\text { canopy } \\
\text { width (m) }\end{array}$ & $\begin{array}{c}\text { Canopy } \\
\left.\text { area } \mathbf{( m}^{\mathbf{2}}\right)\end{array}$ & $\begin{array}{c}\text { Num. } \\
\text { of live } \\
\text { mod. }\end{array}$ & $\begin{array}{c}\text { Num. } \\
\text { of dead } \\
\text { mod. }\end{array}$ & $\begin{array}{c}\text { Bran. } \\
\text { order }\end{array}$ & $\begin{array}{c}\text { Num. } \\
\text { Inflor. }\end{array}$ \\
\hline Min. & 0.05 & 0.11 & 4 & 0.19 & 0.10 & 0.005 & 1 & 0 & 1 & 0 \\
Max. & 1.68 & 1.07 & 11 & 0.80 & 0.59 & 0.100 & 33 & 6 & 5 & 28 \\
N & 38 & 27 & 32 & 26 & 22 & 22 & 38 & 15 & 33 & 12 \\
\hline
\end{tabular}

Table 2 - Minimum, maximum, mean values and respective standard deviations (SD) of dry biomass (g) of each component of Lychnophora ericoides collected in a Cerrado on the Fazenda Água Limpa, Brasília, central Brazil. N is the sample size for each component.

\begin{tabular}{lccccccc}
\hline & Leaves & Branches & Stem & Leaves + Branches & Reprod. Struct & Dead & Total \\
\hline Min. & 1.879 & 0.819 & 1.532 & 1.879 & 0.296 & 0 & 1.879 \\
Max. & 84.452 & 86.882 & 528.857 & 160.83 & 7.736 & 8.547 & 707.83 \\
Mean & 26.049 & 19.559 & 142.123 & 44.064 & 2.985 & 3.028 & 185.382 \\
SD & 24.584 & 18.753 & 139.716 & 42.467 & 2.305 & 20.580 & 177.641 \\
N & 38 & 35 & 38 & 38 & 12 & 15 & 38 \\
\hline
\end{tabular}

Table 3 - Minimum, maximum, mean values and respective standard deviations (SD)for data on the relationship between branch diameter and biomass of Lychnophora ericoides collected in a Cerrado on the Fazenda Água Limpa, Brasília, central Brazil ( $\mathrm{N}=34)$.

\begin{tabular}{lcccccccc}
\hline & $\begin{array}{c}\text { Diam. } \\
(\mathbf{c m})\end{array}$ & $\begin{array}{c}\text { Length } \\
(\mathbf{c m})\end{array}$ & $\begin{array}{c}\text { Length with } \\
\text { leaves }(\mathbf{c m})\end{array}$ & $\begin{array}{c}\text { \% } \\
\text { covered }\end{array}$ & $\begin{array}{c}\text { Num. of } \\
\text { leaves }\end{array}$ & $\begin{array}{c}\text { Leaf biom. } \\
(\mathbf{g})\end{array}$ & $\begin{array}{c}\text { Branch } \\
\text { biomass }(\mathbf{g})\end{array}$ & $\begin{array}{c}\text { Total } \\
\text { biomass }(\mathbf{g})\end{array}$ \\
\hline Min. & 0.38 & 7.5 & 5.0 & 29.7 & 179 & 1.299 & 0.704 & 2.275 \\
Max. & 1.70 & 40.0 & 15.5 & 73.5 & 705 & 10.086 & 15.191 & 24.354 \\
Mean & 0.893 & 19.706 & 19.706 & 51.431 & 327.471 & 4.575 & 4.290 & 8.865 \\
SD & 0.321 & 9.552 & 9.552 & 12.561 & 106.974 & 2.790 & 3.908 & 6.544 \\
\hline
\end{tabular}



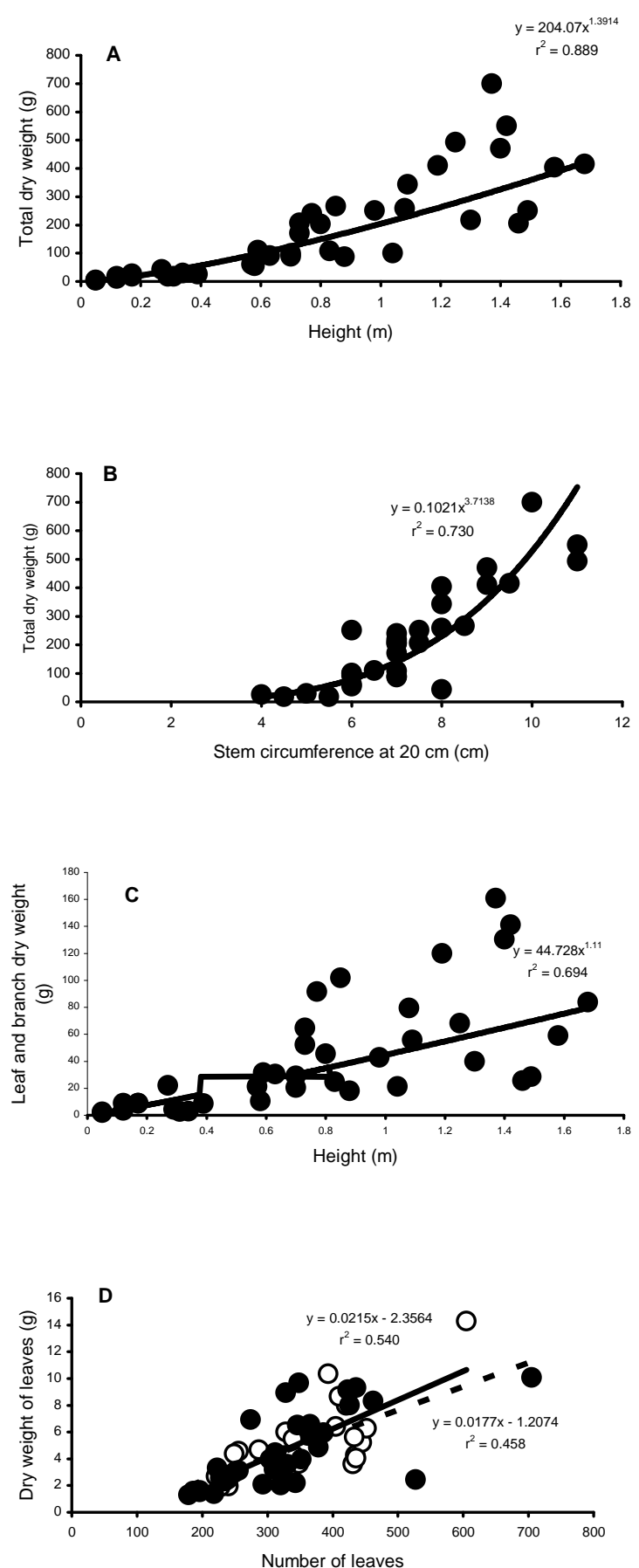

Figure 1 - Relation between total height and total dry biomass (A), Stem circumference at $20 \mathrm{~cm}$ and total dry biomass (B), Total height and combined leaf and branch biomass (C) and Number of leaves and leaf biomass (D) of Lychnophora ericoides collected in a cerrado in the Federal District of Brazil. In figure D the whole line refers to the data set collected using selected branches from whole individuals (filled circles, $\mathrm{N}=38$ ) and the dashed line from the additional data set (open circles, $\mathrm{N}=34$ ) for the relationship between branch diameter and leaf weight. 
In the relationship between branch diameter and leaf biomass (Tab. 3) all combinations among independent variables were significantly correlated $\left(\mathrm{r}_{\mathrm{s}}>0.550, \mathrm{p}<0.001\right)$. The best relation between the basal diameter and leaf biomass was linear ( $\mathrm{Y}$ $\left.=-1.447+0.674 \mathrm{X}, \mathrm{r}^{2}=0.600, \mathrm{p}<0.001\right)$. The slope of the regression lines for the relation between the number of leaves and their biomass was similar for both data sets $\left(\mathrm{F}_{1,58}=0.520, \mathrm{p}=\right.$ 0.472 ) however the $r^{2}$ value for both lines was lower than for the other regressions (Fig. 1D).

\section{DISCUSSION}

The use of non-timber products of plants, such as fruits, oils, fibers, etc is an important aspect in the sustainable use of ecosystems and the use of these products can provide an alternative source of income for these communities. In Brazil, the monetary value of several native species is routinely quantified by IBGE (Ministerio de Planejamento, Orçamento e Gestão, 2003; Wunder, 1999), however for the vast majority of species there are no data. One of the primary questions for the sustainable use of native species is related to the amount of biomass present (Fleig et al., 2003; Rondon Neto and Gama, 2003) and for the sustainable management of Lychnophora ericoides, or any other species whose leaves are the primary resource, the possibility of estimating their biomass a priori is important. However it is also important to consider the ecological effects of removal of the explored resource on the species (Ticktin, 2004).

Allometric relations have been effectively used to estimate above ground dry weight of the combustible material present in several shrub species in Argentina (Hierro et al., 2000) and available forage for shrubs in Baja California, Mexico (Dominguez-Cadena et al., 2003). A good predictive relationship between total height and total dry biomass was derived for $L$. ericoides, but the relationship was weaker when only leaves or both leaves and branches were considered. The poorer relationship between number of leaves and leaf biomass is caused by a large variation in leaf size among individuals (Hay, unpublished). Since Silva and Hay (2003) showed that removal of over $50 \%$ of the branches and leaves provoked higher mortality rates of individuals any sustainable management plan for this species must harvest only a small amount of the canopy to permit regrowth by the individuals harvested. The development of these equations can be considered as a first step towards permitting a rapid assessment of the amount of dry biomass present in native populations of $L$. ericoides and permitting a rational exploration of the populations.

\section{ACKNOWLEDGEMENTS}

B. S. Andrade received a scholarship from the $\mathrm{CNPq} / \mathrm{PIBIC}$ program at $\mathrm{UnB}$ during this project. We would also like to thank the reviewers of this manuscript for their comments and suggestions.

\section{RESUMO}

Para o uso sustentável das espécies vegetais nativas o conhecimento da quantidade de biomassa disponível é necessário. O objetivo deste estudo foi verificar as relações alométricas para Lychnophora ericoides Mart., um recurso extrativista importante na região dos Cerrados. $\mathrm{Na}$ Fazenda Água Limpa da Universidade de Brasília, 38 indivíduos desta espécie foram medidas no campo, a parte aérea foi cortada, separada em componentes de folhas, galhos e tronco e estas componentes foram secas e pesadas. As melhores equações de regressão para estimar a biomassa foram geométricas e o melhor ajuste foi entre altura total e biomassa total $\left(r^{2}=0.923\right)$. As partes economicamente exploradas, as folhas e ramos, contribuíram com aproximadamente $20 \%$ do peso seco total desta espécie, mas a equação para estimar a biomassa destas componentes teve um ajuste mais fraco $\left(r^{2}=0.694\right)$. A relação entre $o$ diâmetro do ramo e a biomassa das folhas $\left(r^{2}=\right.$ 0.600) foi semelhante à relação entre altura $\mathrm{e}$ biomassa foliar. $\mathrm{O}$ desenvolvimento destas equações é o primeiro passo para a implementação de planos de manejo sustentável para esta espécie.

\section{REFERENCES}

Alho, C.J. and Martins, E.R. (1995), De grão em grão o cerrado perde espaço (Cerrado - impactos do processo de ocupação). Brasília : WWF - Fundo Mundial para a Natureza. 
Analytical Software. (2003), Statistix 8.0. Tallahassee : Analytical Software.

Ayres, M,; Ayres, M. D.; Ayres, L. and Santos, A. A. S. dos. (2003), BioEstat 3.0: aplicações estatísticas nas áreas de ciências biológicas e médicas. Belém : Sociedade Civil Mamirauá/CNPq.

Borges Filho, H. C. and Felfili, J. M. (2003), Avaliação dos níveis de extrativismo da casca de barbatimão (Stryphnodendron adstringens (Mart.) Coville) no Distrito Federal, Brasil. Rev. Arv., 27, 735-745.

Borsato, M. L. C.; Grael, C. F. F.; Souza, G. E. P. and Lopes, N. P. (2000), Analgesic activity of the lignans from Lychnophora ericoides. Phytochemistry, 55, 809-813.

Cairns, M. A.; Olmsted, I.; Gramados, J. and Argaez, J. (2003), Composition and aboveground tree biomass of a dry semi-evergreen forest in Mexico's Yucatan peninsula. For. Ecol. Manag., 186, 125-132.

Carvalho, A. R. (2004), Popular use, chemical composition and trade of Cerrado's medicinal plants (Goiás, Brazil). Environment, Development and Sustainability, 6, 307-316.

Clark, D. A.; Brown, S.; Kirklighter, D. W.; Chambers, J. Q.; Thomlinson, J. R. and Ni, J. (2001), Measuring net primary production in forests: concepts and field methods. Ecol. Appl., 11, 356-370.

Coile, N. C. and Jones, S. B. (1981), Lychnophora (Compositae: Vernoniaceae), a genus endemic to the Brazilian planalto. Brittonia, 33, 528-442.

Dominguez-Cadena, R..; Guillén-Trujillo, A.; Leon-dela-Luz, J. L. and B. Murillo-Amador. (2003), Estimacíon y disponibilidad forrajera de arbustos en Baja California Sur, México. Interciência, 28, 229233.

Ferreira, S.H.; Barata, L. E. S.; Salles; S. L. M.; Queiroz; S. R. R.; Helly Neto, N. E.; Corazza, R. and Farias, R. C. (1998), Medicamentos a partir de plantas medicinais no Brasil. Rio de Janeiro : Academia Brasileira de Ciencias.

Filgueiras, T. S. and Pereira, B. A. S. (1994), Flora do Distrito Federal. In: Pinto, M.N. (Ed.). Cerrado caracterização, ocupação e perspectivas. Brasília : EdUnB/SEMATEC. pp. 345-404.

Fleig, F. D.; Schneider, P. R. and Finger, C. A. G. (2003), Influencia do espaçamento e idade da brotação na morfometria de povoamentos de Ilex paraguariensis St. Hil. Cien. Flor., 13, 73-88.

Franco, A. C. (1998), Seasonal pattern of gas exchange, water relations and growth of Roupala montana, an evergreen savanna species. Pl. Ecol., 136, 69-76.

Goedert, W. J.; Lobato, E. and Wagner, E. (1980), Potencial agrícola da região dos cerrados brasileiros. Pesq. Agropec. Bras., 15, 121-129.

Hierro, J. L.; Branch, L. C.; Villarreal, D. and Clark, K. L. (2000), Predictive equations for biomass and fuel characteristics of Argentine shrubs. J. Range Manag., 53, 617-621.
Hoffmann, W. A. and Franco, A. C. (2003), Comparative growth analysis of tropical forest and savanna woody plants using phylogenetically independent contrasts. J. Ecol., 91, 475-484.

Keller, M.; Palace, M. and Hurtt, G. (2001), Biomass estimation in the Tapajos National Forest, Brazil. Examination of sampling and allometric uncertainties. For. Ecol. Manag., 154, 371 - 382.

Kuntschik, G. and Bittencourt, M. D. (2003), Quantificação da fitomassa florestal aérea de cerrado e cerradão através de imagen de satélite. Anais XI SBSR, INPE, 2201-2208.

Ludwig, J. A.; Reynolds, J. F. and Wilson, P. D. (1975), Size-biomass relationships of several Chihuahuan desert shrubs. Am. Mid. Nat., 9, 451-461.

Ministerio de Planejamento, Orçamento e Gestão, IBGE. (2003), Produção de extração vegetal e da silvicultura, v. 18. Rio de Janeiro : IBGE.

Moreira, A. G. and Klink, C. A. (2000), Biomass allocation and growth of tree seedlings from two contrasting Brazilian savannas. Ecotropicos, 13, 4351.

Pires, M. O. and Scardua, F. P. (1998), Extrativismo vegetal não madeireiro no Cerrado. Brasília : ISPN.

Reis, M. G. F.; Kimmins, J. P.; de Rezende, G. C. and Barros, N. F. (1985), Acúmulo de biomassa em uma sequência de idade de Eucalyptus grandis plantada no Cerrado em duas áreas com diferentes produtividades. Rev. Árv., 9, 149-162.

Rondon Neto, R. M. and Gama, J. R. V. (2003), Biomassa acima do solo de espécies herbáceas e subarbustivas com potencial medicinal em uma vegetação secundária. Ciên. Flor., 13, 19-24.

Ruggiero, P.G.C. and Zaiden, L. B. P. (1997), Estudos de desenvolvimento de Vigueira robusta Gaedn., uma Asteraceae do Cerrado. Rev. bras. Bot., 20, 1-9.

Sakamoto, H. T.; Flausino, D.; Castellano, E. E.; Stark, C. B.; Gates, P. J. and Lopes, N. P. (2003), Sesquiterpene lactones from Lychnophora ericoides. J. Nat. Prod., 66, 693-695.

Sawyer, D.; van der Ree, M.; Pires, M. and Oliveira, M. (1997), Comercialização de espécies vegetais nativas do Cerrado. Brasília : ISPN.

Silva, D. M. S. and Hay, J. D. (2003), Efeitos da poda na sobrevivência e na produção de ramos de Lychnophora ericoides (Compositae: Asteraceae). In: Anais de Trabalhos Completos - VI Congresso de Ecologia do Brasil. Fortaleza : Sociedade de Ecologia do Brasil. pp. 425-427.

Ticktin, T. (2004), The ecological implications of harvesting non-timber forest products. J. Appl. Ecol., 41, 11-21.

Veja, F. V. A.; Bovi, M. L. A.; Spiering, S. H. and Godoy Junior, G. (2004), Relações alométricas para estimativa da fitomassa aérea em pupunheira. Hort. Bras., 22, 104-108. 
Vieira, R. F. and Martins, M. V. M. (2000), Recursos genéticos de plantas medicinais do Cerrado: uma compilação de dados. Rev. bras. Plantas Med., 3, 1336.

Vieira, R. F. and Silva, S. R. (2002), Estratégias para conservação e manejo de recursos genéticos de plantas medicinais e aromáticos. Brasília, EMBRAPA/IBAMA.

Whittaker, R.H. (1968), Dimension and production relations of trees and shrubs in the Brookhaven forest, New York. J. Ecol., 56, 1-25.

Wunder, S. (1999) Value determinants of plant extrativism in Brazil (Texto para discussão No. 683, nov 1999). Rio de Janeiro : IPEA.

Received: March 07, 2005;

Revised: December 07, 2005;

Accepted: March 09, 2007. 